\title{
Histomorphological evaluation of the digital coronary region at different fetal development stages of Holstein cattle
}

\author{
[Avaliação histomorfológica da região coronária digital em diferentes fases de \\ desenvolvimento fetal de bovinos da raça Holandesa]
}

\author{
R.E. Rabelo ${ }^{1}$, V.A.S. Vulcani ${ }^{1}$, F.J.F. Sant'ana ${ }^{2}$, C.R.O. Lima $^{3}$, H.T. Dutra ${ }^{1}$, \\ A.S. Rabbers ${ }^{4}$, L.A.F. Silva ${ }^{1}$ \\ ${ }^{1}$ Universidade Federal de Goiás - UFG - Jataí, GO \\ ${ }^{2}$ Universitdade de Brasília - UnB - Brasília, DF \\ ${ }^{3}$ Agriculture Defense Agency of the State of Goias - Jataí, GO \\ ${ }^{4}$ Aluno de pós-graduação - Universidade Federal de Goiás - UFG - Jataí, GO
}

\begin{abstract}
The scientific literature lacks detailed morphological descriptions of the histological development and cell differentiation of fetal bovine hoof. In this study, 40 extremity members of Holstein bovine fetuses were collected and divided into four groups (G1 to G4) based on the estimated age. Fragments were removed from wall and sole, processed and stained with hematoxylin - eosin (HE) for light microscopy observation. In G1, it was found that the epidermis was very thin, including keratinocyte layers and clusters of mesenchymal cells. In group G2 it was observed that the thickness of the epidermis covering the limbs remained variable and laminar corium developed in the germinal layer. In group G3 it was noted that in the germinal epithelium there were papillae in little advanced development and cells of the stratum corneum in the initial process of keratinization. In G4, the epidermis was well developed with layers distributed homogeneously, containing symmetrical and long papillae and intense production of keratin. In this work, the most important cellular events for the formation of the fetal hoof in Holstein cattle were first described in different stages of their formation.
\end{abstract}

Keywords: bovine hoof, podiatry, fetal development

\section{RESUMO}

A literatura científica carece de descrições morfológicas detalhadas sobre o desenvolvimento histológico e diferenciação celular do casco fetal bovino. Neste estudo, 40 extremidades de membros de fetos bovinos da raça Holandesa foram coletados e divididos em quatro grupos (G1 a G4) com base na estimativa da idade. Desses membros, foram retirados fragmentos da parede e sola, processados e corados por hematoxilina-eosina (HE) para observação em microscopia óptica. No grupo G1, observou-se que a epiderme era bastante delgada, incluindo camadas de queratinócitos e conjuntos de células mesenquimais. No grupo G2, foi observado que a espessura da epiderme, cobrindo as extremidades dos membros, permaneceu variável, e o cório laminar desenvolveu-se na camada germinativa. No grupo G3, notou-se, no epitélio germinal, papilas em desenvolvimento pouco avançado e células da camada córnea no processo inicial de queratinização. No grupo G4, a epiderme apresentava-se bem desenvolvida, com camadas distribuídas de forma homogênea, contendo papilas simétricas e longas e com intensa produção de queratina. Neste trabalho, os eventos celulares mais importantes para a formação do casco fetal em bovinos da raça Holandesa foram descritos pela primeira vez, em diferentes etapas da sua formação.

Palavras-chave: casco bovino, podologia, desenvolvimento fetal

Recebido em 2 de abril de 2014

Aceito em 3 de outubro de 2014

E-mail: rabelovet@yahoo.com.br 


\section{INTRODUCTION}

The hoof is a special cutaneous structure that consists of epidermis and its keratinized derivatives. It features strong interconnection to the underlying dermis, forming closely associated and interspersed epidermal and dermal papillae. The bovine hoof morphological regions include periople, crown, wall, sole and bulb (Banks, 1992; Mulling and Budras, 2011). All regions of the hoof feature epidermis separated from the underlying dermis by a basement membrane (Greenough, 2007). The epidermis covers the dermis forming horn tubules, extending throughout the length of the corneal tissue, as a continuation of dermal papillae (Mulling and Budras, 2011).The cornified cells in the horn tubules are arranged in a spiral, which helps to decrease the compression when the hoof is pressed against a hard surface (Rezaian, 1998).

Although the anatomical descriptions of adult bovine (Banks, 1992; Dellman, 1993; Bacha, 2003; Greenough, 2007) and equine (Stump, 1967) hooves are well known, and many studies have been conducted on the morphometric development of hooves in different fetal sheep (Rezaian, 1998) and equine (Bragulla and Homberger, 2007) stages, the scientific literature lacks detailed morphological descriptions focusing on the histological development and differentiation of cattle fetal hoof.

Considering the frequency of hoof diseases in cattle and the economic impact that those injuries represent on the productivity of dairy cows, the knowledge of morphological and morphometric features along the fetal life until adulthood may provide useful support for the prevention and control of different digital diseases in that species. Therefore, this study aimed to describe the morphological development of the digital coronary region in different stages of Holstein cattle fetal life.

\section{MATERIAL AND METHODS}

In this study, 40 (thoracic or pelvic) hooves of Holstein cattle fetuses were used, obtained from inspected slaughterhouses in the municipality of Jatai/GO, at the Federal University of Goias, Campus Jatai, from February/2012 to October/2013. The hooves were divided into four groups based on the fetal age estimate, according to Grunert and Birgel (1984), as follows:
G1 ( $n=10)$ - age from 45 to 60 days;

G2 ( $n=10)$ - age from 61 to 90 days;

$\mathrm{G} 3(\mathrm{n}=10)$ - age from 91 to 180 days;

G4 $(n=10)$ - age from 181 to 260 days.

Aided by a handsaw and walrus $0.5-1 \mathrm{~cm}$, thick fragments of the wall and sole were collected from every sample, according to Rezaian (1998). The samples were subsequently fixed in buffered formalin at $10 \%$ for 24 hours, routinely processed for histopathology and stained by hematoxylin-eosin (HE). The histological slides were evaluated through optical microscopy, with emphasis in the formation and differentiation of the epidermal papillae.

The present research was approved by the Ethics Committee for Animal Experimentation of the Federal University of Goias, as Protocol 093/11.

\section{RESULTS}

In the group G1, it was noted that 45-day fetuses showed limbs as small appendages. During that period, the epidermis was quite thin, including layers of keratinocytes and groupings of mesenchymal cells on the underlying dermis. In fetuses aged between 55-60 days, difference was observed in the thickness of the epidermis in different points of the end of the limb. On the wall, the epidermis was thicker than the sole. The wall consisted of a basal layer of columnar cells with two or three upper layers of cuboidal cells in the germinal layer, whereas in the region corresponding to the sole, only one cuboidal layer was observed and three or four layers of vacuolated spinous cells, being the latter covered by a thin layer of granular cells (Figure 1).

In $\mathrm{G} 2$, at 70 days, it was found that the thickness of the epidermis covering the ends of the limbs remained variable and the laminar corium developed itself in the germinal layer, underlying the coronary corium. The cells of the spinous layer above the laminar corium gradually began the grouping process by forming epidermal indents on the basal layer, causing the epidermis to increases its thickness (Figure 2A). The occasional, irregular and discrete formation of keratin was noted inside the epidermis (Figure 2A). As of 80 days, the formation and initial differentiation of the epidermal papillae was evident, where the keratinocytes, already in considerable number, were projected digitally to the dermis, concentrating in those structures (Figure 2B). 


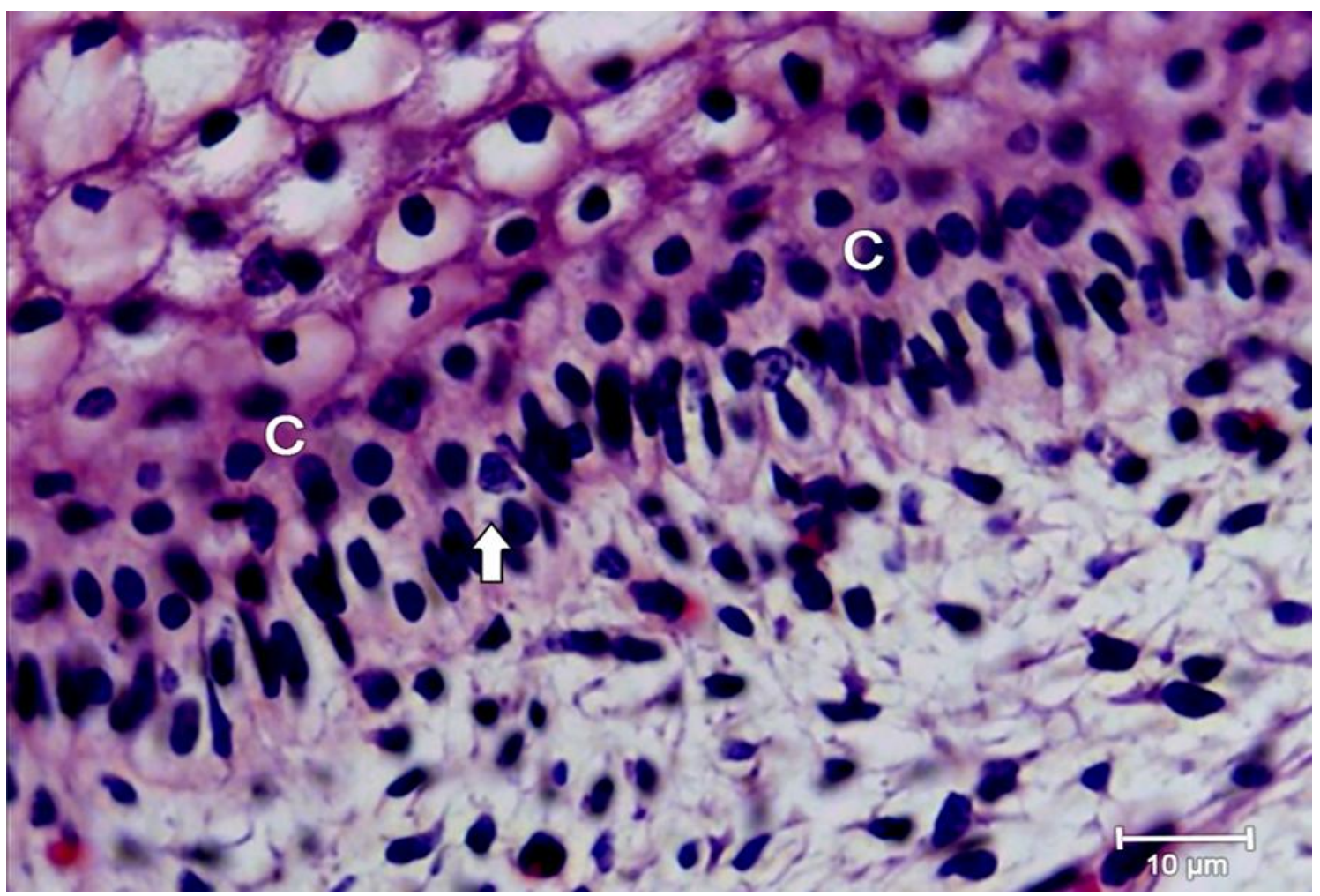

Figure 1. Group G1. In A, microscopic structure of the epidermis of 60-day bovine fetuses. Notice the germinal layer with a cylindrical basal layer (arrow), two or three upper layers of cuboidal cells (E) and the spinous layer with at least four layers of vacuolated cells. HE

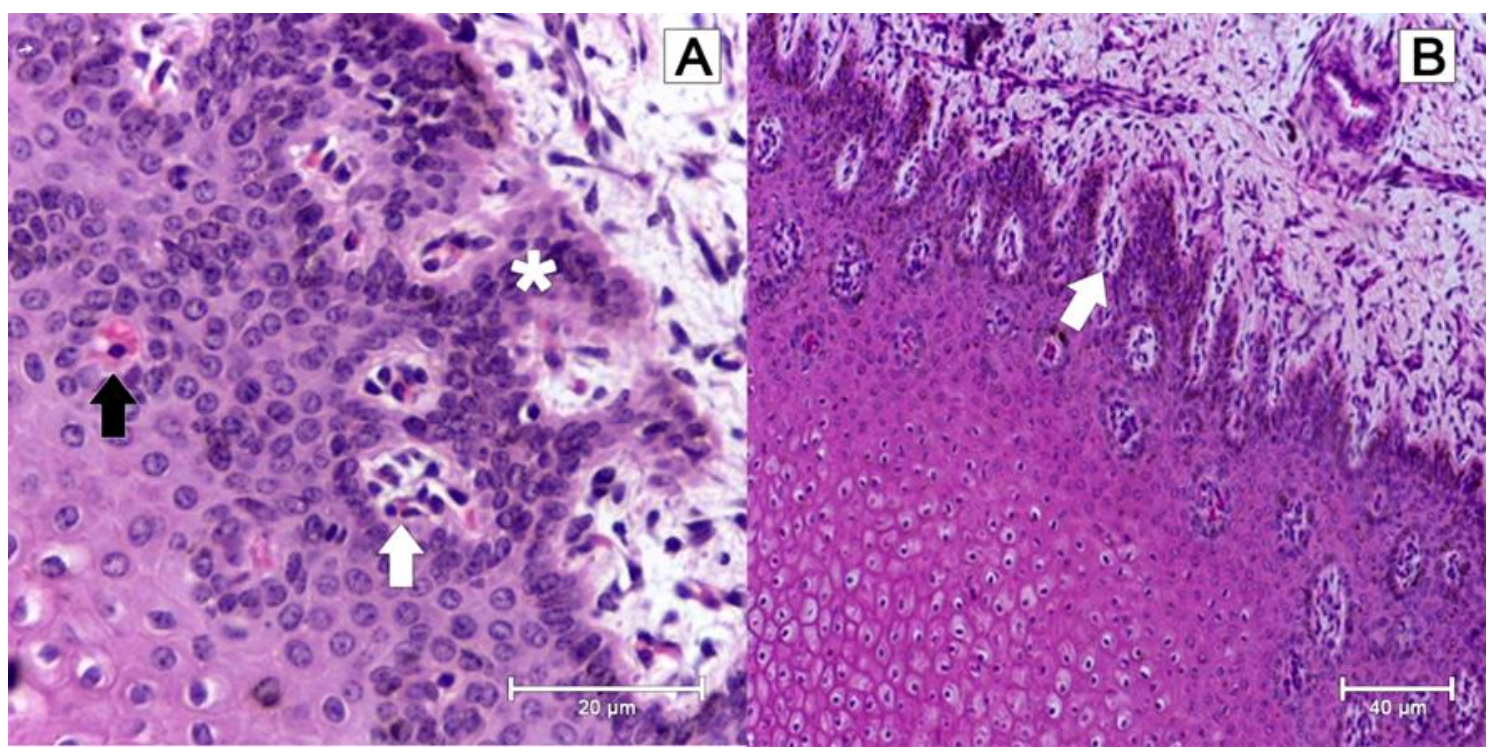

Figure 2. Group G2. In A, microscopic structure of 70-day bovine fetuses epidermis. Notice the distribution with a tendency to agglomeration of keratinocytes (white arrow), the discreet formation of keratin (dark arrow) and the beginning of the formation of the epidermal papillae along the layers of spinous cells (asterisk). HE. In B, microscopic structure of 70-day bovine fetuses epidermis. Notice the formation and initial differentiation of the epidermal papillae (white arrow). HE 
In group G3, in 91 to 120-day hooves, the germinal epithelium with papillae in moderate development and the cells of the corneal layer on initial process of keratinization were noted. It was evident that the germinal cells split intensely, composing numerous layers of spinous cells. When analyzing the development of the epidermal papillae, it was noticed that they developed themselves individually, however, at that stage, there were irregular bifurcations (similar to "Y") where a single papilla originated two other thinner papillae (Figure 3A and 3B). At that time, the keratinocytes of the spinous layer still presented cytoplasmic vacuolations, however with less intensity than in G2. In the hooves aged between 120 and 180 days, the keratinization intensified. The production of keratin was still moderate; however, the formation of horn tubules was not observed (Figure 3B).

In group $\mathrm{G} 4$, the epidermis was well developed with homogeneous distribution of its layers and long and symmetrical epidermal papillae. Furthermore, the production of keratin occurred more intensely, forming a thick layer on the spinous layer. In that stage, it was evidenced that the formation of horn tubules still remained discreet and that the present tubules were perpendicular to the epidermal papillae, with small diameter and distributed randomly (Figure 4).

\section{DISCUSSION}

The histological findings observed in the hooves aged up to 60 days, concerning the formation of small appendages in the region of the limbs, groups of mesenchymal cells and thickening of the germinal layer were very similar to the fetal development of the sheep hoof (Rezaian, 1998; Hamrick, 2001). Studies conducted by Bragulla and Homberger (2007) evaluating equine fetuses at different ages and using transmission electronic microscopy showed that fetuses aged less than 60 days presented a stratified epithelium feature in the beginning of keratinization. However, in this study, it was observed that the keratinization occurred mildly in animals with age ranging from 61 to 90 days (G2) and more pronouncedly in animals aged between 91 and 180 days (G3).

The development of epidermal papillae starts with the agglomeration of keratinocytes in random groups that, in a later stage, are organized similarly to descriptions by Rezaian (1998) and Bragulla and Homberger (2007) in sheep and equine fetuses. However, in those species, the development of papillae took place around the 70 days of life, while the development in Holstein animals was around the 80 days of life. The formation of groups gives rise to isolated or united papillae, which split up later. That apparently disorganized event originates a regular organization of a layer of papillae to the formation of the keratin layer. The process of keratinization in the end of the locomotor limb for the formation of the rudimentary hoof in the fetal stage is characterized by loss of epidermis cell nuclei as a process of cellular differentiation (Bragulla and Homberger, 2009).

Although not detailing the dynamics of development and formation of horn tubules during the fetal stage, different research employing other species as experimental models have also mentioned that the development and consequently the formation of horn tubules may only be evidenced in the final stage of fetal life (Banks, 1992; Rezaian, 1998; Bragulla and Homberger, 2009), corroborating with the findings of this research that has detected their presence as of the third quarter of pregnancy (180 days). Therefore, it was found that in the final third of the gestational period of cattle, the fetal hoof is practically formed and the configuration of keratin is defined. What occurs along the ontogenetic development is the growth of structures and tissues that constitute the digit and the growth and thickening of the keratin. 

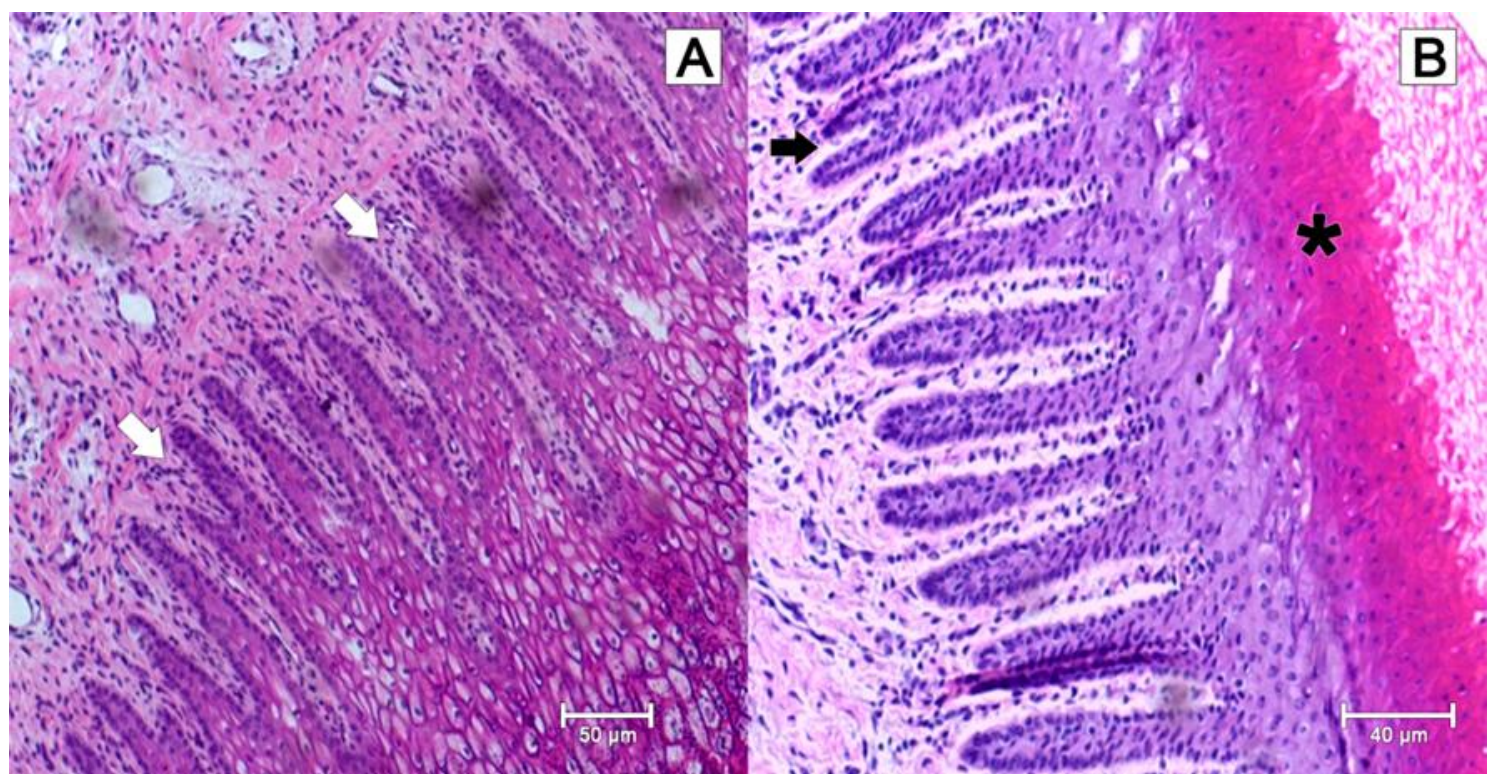

Figure 3. Group G3. In A, the epidermis of 90-day bovine fetuses. Notice the formation of epidermal papillae that tend to start grouped to individualize themselves later (white arrows). In B, check the epidermal papillae under development (dark arrow) and the intensified production of keratin, however, with no composition in horn tubules (asterisk). HE

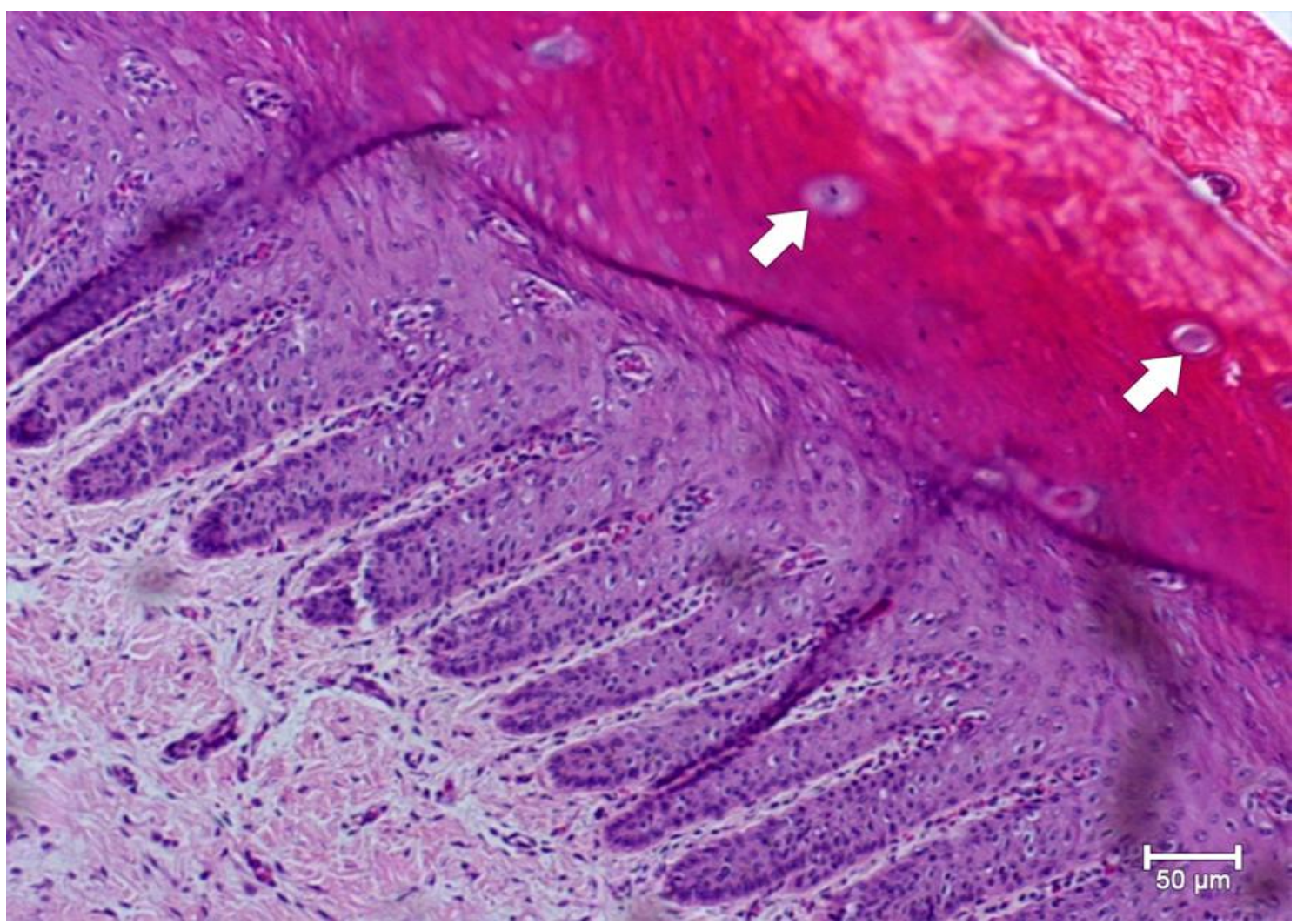

Figure 4. Group G4. Microscopic structure of the epidermis of 240-day bovine fetuses. Notice the individualization of the epidermal papillae and the well-developed corneal layer, in which the beginning of the formation of horn tubules is evident (white arrows). HE 


\section{CONCLUSION}

In this work, prime cellular events of the formation of Holstein cattle fetal hoof were described for the first time, at different stages of its formation.

\section{ACKNOWLEDGMENTS}

This study was supported by the National Council for Scientific and Technological Development (CNPq).

\section{REFERENCES}

BACHA, W.J.; BACHA, L.M. Atlas colorido de histologia veterinária. 2. ed. São Paulo: Roca, 2003. 457p.

BANKS, W.J. Histologia Veterinária Aplicada. 2. ed. São Paulo: Manole, 1992. 629p.

BRAGULlA, H.H.; HOMBERGER, D.G. The role of the specific, profilaggrin-containing keratohyalin granules in the developing epidermis of the fetal horse hoof. Pferdeheilkunde, v.23, p.5-20, 2007.

BRAGULLA, H.H.; HOMBERGER, D.G. Structure and functions of keratin proteins in simple, stratified, keratinized and cornified epithelia - a review. J. Anat., v.214, p.516-559, 2009.
DELLMAN, H.D. Histologia veterinária. 2. ed. Acribia: Zaragoza, 1993. 398p.

GREENOUGH, P.R. Bovine laminitis and lameness - A hands-on approach. Philadelphia: Saunders Elsevier, 2007. 328p.

GRUNERT, E.; BIRGEL, E.H. Obstetrícia veterinária. 2. ed. Porto Alegre: Sulina, 1984. $323 \mathrm{p}$.

HAMRICK, M.W. Development and evolution of the mammalian limb: adaptive diversification of nails, hooves and claws. Evol. Dev., v.3, p.355-363, 2001.

MULLING, C.; BUDRAS, K.D. The hoof. In: Budras, K.D.; Habel, R.E. Bovine Anatomy. Hannover: Schlutersche GmbH, 2011. 138p.

REZAIAN, M. Histological study of the hoof development in sheep. Kafkas Univ. Vet. Fak. Derg., v.53, p.92-96, 1998.

STUMP, J.E. Anatomy of the normal equine foot, including microscopic features of the laminar region. J. Am. Vet. Med. Assoc., v.151, p.1588-1598, 1967. 